\title{
LATIN AMERICAN DIPLOMACY
}

Sean W Burges (sean.burges@anu.edu.au)

Deputy Director, Australian National Centre for Latin American Studies, ANU

Fabrício H Chagas Bastos (fabricio.chagasbastos@anu.edu.au)

Postdoctoral Fellow, Australian National Centre for Latin American Studies, ANU

\section{Forthcoming in Pauline Kerr, Costas Constantinou and Paul Sharp, eds, The Sage Handbook of Diplomacy (London: Sage Publishing, forthcoming/2016).}

After the close of the 2003 World Trade Organization ministerial meeting in Cancun, Mexico, United States Trade Representative Robert Zoellick unleashed a stinging attack on Brazil and its Latin American partners in the G-20 trade negotiating coalition. Lamenting the failure to reach agreement on the US/EU proposal to conclude the Doha round, Zoellick (2003) bemoaned Brazil's "tactics of confrontation", refusal to compromise, and insistence on a "massive list of required changes" to the chairperson's discussion text. These tensions between the Brazilian-led G20 negotiating coalition and the US offer a highly illustrative entry point to understanding the key elements of contemporary Latin American diplomacy, the subject of this chapter. In order to grapple with the practice and precepts of Latin American diplomacy we will draw out five points embedded within post-Cancun rhetorical fracas and amplify them through reference to other cases and the conceptual thinking of scholars and analysts based in the region. The approach we take in our analysis of Latin American diplomacy is predominantly at the state level, examining the patterns and habits of interaction exhibited by governments in the region.

\section{Changing traditional views: Latin America is not a homogenous entity}

Perhaps the cleverest element of Zoellick's blast against Brazil was the emphasis on how the G20 not only violated pan-Southern solidarity by rejecting a text from the Thai WTO Director General Supachai Panitchpakdi, but also abrogated the supposedly entrenched idea of intraLatin American unity. As Zoellick highlighted, the text blocked by the G20 was drafted by the WTO's General Council chairperson Carlos Pérez del Castillo, Uruguay's ambassador to the organization. The meeting itself was chaired by Mexican foreign minister Luis Ernesto Derbez, who attempted to broker an agreement between the contending parties.

In his ire Zoellick appeared to be assuming Latin America can be viewed as a homogeneous unit with consistent shared interests and attitudes. The region is instead comprised of countries possessing a wide range of geographic, demographic, economic and historical characteristics impacting their independent foreign policy positions. 'Latin America' as a 'unity' is itself an externally devised notion floated by the French in the 1830s in an effort to create an implicit sense of alliance between the region and Romance-language European countries engaged in a struggle with their Anglo-Saxon and Slavic neighbours.

The French idea of 'Latin America' as a contiguous unit did stick in the Washington policy consciousness during the 1800s when gunboat diplomacy undergirded US efforts to establish the Western Hemisphere as its exclusive zone of influence. Repeated iterations of US policy towards the Americas took a rather simplified approach to exerting hegemony over the region through approaches such as the Monroe Doctrine (1823), the 'Big Stick' policy (1901), 'Good Neighbour' Policy (1933), the 'Alliance for Progress' (1961) and the 'Enterprise for the 
Americas' initiative (1990). In aggregate these initiatives reinforced belief in US dominance over the region, an analytical assumption that remains predominant in much English-language work on Latin American foreign relations (for example, Hakim, 2003; Oppenheimer, 2007). While attractive for the US, regional countries found themselves somewhat marginalized and were left feeling alternately undervalued, left out, or bullied.

While there has been important variation in how Washington has attempted to manage the different countries, the general tone and approach has started from a remarkably similar place whether the US counterpart was Brazil, Bolivia, Costa Rica or Mexico. Even the regional organizations spanning the hemisphere such as the Organization of American States have been seen as opportunistic tools for Washington, not forum within which to engage in serious problem-solving or issue management. Per the tradition initiated with the Monroe Doctrine of 1823, Latin America has remained a question of bilateral management and control for Washington that holds little interests absent crises requiring attention from the highest level of policy makers, a situation amplified since the 9/11 attacks and launch of the War on Terror (Hakim, 2006). In some respects such simplification makes sense to US policy makers preoccupied with Islamic radicalization and the spread of weapons of mass destruction. With intra-continental war in the Americas highly unlikely, the security concerns dominating policy are of a non-traditional variety such as nacrotrafficking, transnational criminal networks, and migration, all areas that receive more of a policing response from Washington than serious multilateral security engagement. South America's states implicitly recognize that, far from being outside of Washington's geopolitical concerns, they are, on the contrary, a preferential area for the United States' preventive, and perhaps even hasty, unilateral interference (Villa, Rodrigues and Chagas Bastos, 2015). Frustration with the simplistic approach to regional security issues from the US has combined with commodity boom-fuelled economic independence to further feed a differentiation of foreign policies in the Americas and a sustained drift away from reliance upon the US.

Northern tendencies to reduce the varied countries of Latin America to a single stereotype is in part explicable by three important characteristics of the region's foreign relations and integration into the international system. First is a geographic consideration, namely that Latin America is a long way from the most active laneways of US and European history over the last two centuries: the North Atlantic and the Middle East. Married to this is the second factor, which is the decidedly limited ability, let alone desire of any country in the region to project power into other parts of the world. World War Two saw only one regional country - Brazil actively enter the hostilities, and this at the last moment and just in time to join the invasion of Italy (Lochery, 2014). In more contemporary times Latin American countries have either stood out for their refusal to be drawn into foreign entanglements - Chile was severely politically castigated by the US for dissenting in the UNSC on the 2003 invasion of Iraq (Muñoz, 2008) - or limited themselves to generally modest peace-keeping contributions, often in coalition with other regional countries (Kenkel, 2013). Bellicosity would thus seem to be outside the 'Latin' diplomatic character, a factor reinforced by the notable shortage of major inter-state armed conflicts in the region, with the most recent serious one being the 1932-1935 War of the Chaco between Bolivia and Paraguay.

The combination of somewhat comparable histories of Iberian colonization, geographic continuity on a common continental land mass, and similarities in language - Brazilian diplomats speak fluent Spanish - combines with an absence of serious inter-state armed conflict to help build a sense that the region is harmonious and relatively homogenous. Overlooked in this surface-level sketch is the persistence of entrenched tensions and conflicts 
in the region. Brazil and Mexico have soft contending ambitions for regional leadership, with Argentina often staking its own claim as well. The Bolivian armed forces are lead by an admiral as a sustained note of protest against what it claims as Chile's illegal seizure of its coastal provinces during the 1879-1883 War of the Pacific. Peru, too, has border complaints against Chile from that nineteenth century war and only recently settled an additional border conflict with Ecuador in 1998, a dispute which dated from 1942 and saw a series of skirmishes and casualties throughout the twentieth century. Venezuela has on going border disagreements with its littoral neighbours and went so far as to bomb Guyanese dredging barges in 2007 (Starbroek News). Costa Rica and Nicaragua continue to bicker over dispute border territory and had entered into arbitration in The Hague in 2010.

If we expand the list of territorial disputes in the region to include trade disagreements, political contretemps, historical misunderstandings and other forms of regional rivalry we end up with a fairly extensive catalogue of dissent and discord in Latin America. Indeed, simply keeping track of the intra-Mercosur disputes between Argentina and Brazil along with the related attempts at bilateral relationship management has resulted in a substantial subdiscipline in the fields of regionalism and Latin American studies. What matters for understanding Latin American diplomacy is that these very real disagreements have a tendency to become of second-order importance to regional diplomats when faced with the need to unify in the face of pressure from a US or Europe that either dismissively tries to aggregate the region into a single, easy to manage unit, or pursues a strategy of divide and conquer to maintain implicit and explicit dominance. This pressure has had a major influence on how Latin American countries approach diplomacy and how they self-consciously exploit the externally created identity of Latin America.

- Latin America is a region of heterogeneous countries, each with important differences in history, culture, geography, economics and society.

- The US has a historical tendency to treat the region as a homogenous bloc, a habit repeated by other extra-regional actors.

- Latin America stands out for the absence of war as a dispute resolving mechanism.

\section{Not quite unity, not quite coalition}

As events at the 2003 Cancun WTO ministerial and the subsequent round of defections and new memberships in the G20 negotiating coalition demonstrated, there is an active recognition amongst Latin American countries that from time to time there will be significant policy differences in international affairs. Where the region differs significantly from other areas of the world is that episodic or even lasting differences on a particular foreign policy issue are not seen as a source of crisis or harbinger of collapsing bilateral relations. Linguistic similarities and a certain degree of cultural affinity across the region have combined with a sense of ever-present pressure from the US to create if not agreement amongst the region's actors, at least a habit of speaking before leaping. The result is certainly not a unity in diplomatic practice or an absence of conflict, but rather the rise of something unique to the cultural and political circumstances of Latin America.

Having just suggested it is a mistake to view Latin America as homogenous unit, there are a number of cultural, historical and linguistic characteristics that nevertheless make it considerably easier for the region's leaders to communicate quickly and fluently. Married to this are a combination of regional force balance and the geographical isolation of border areas to make traditional notions of bandwagoning and balancing from the realist school of 
international relations unusual diplomatic strategies in the region (Flemes and Wehner, 2013; Schenoni, 2014). In place of these US and European-informed approaches to the creation of order is a more legalistic approach emphasizing negotiation and an almost juridical approach to the management of international affairs.

Thanks to an accommodative and legalistic predilection for talking through disagreements, Latin America has become notable for the absence of inter-state conflicts. The 1932-1935 Chaco War between Paraguay and Bolivia dates as the last significant inter-state war in South America, far outmatching in seriousness the 1969 'Football' war between El Salvador and Honduras (Farcau, 1996; Cable, 1969). Although there are unsolved disputes in the region like the Chile-Peru maritime border dispute and Bolivia's complaints Chile illegally seized Antofagasta during the 1879-1883 War of the Pacific, resolution is consistently sought through negotiation and arbitration, not armed invasion. Even when conflict has erupted, such as the as brief periods of shooting between Ecuador and Peru in 1995 or Venezuela's muscular approach to disputed territories with Colombia and Guyana, the tensions appear reluctant and are quickly brought to the negotiating table by other regional countries. This sort of accommodative approach to potential disputes has a long historical tradition, extending as far back as the 1494 Treaty of Tordesillas, which saw Portugal and Spain peacefully accept Papal mediation to divide the 'New World'. While the intervening actors have subsequently changed and the process become more regularized over the last fifty years, the fundamental tendency to avoid armed-conflict remains.

Perhaps the best theorizing of the lack of inter-state armed hostility with Latin America can be found in the concertación approach to diplomatic management advanced by Argentine scholar Federico Merke (2015). The term concertación has no simple translation into English, being a reflection of an Ibero-American tradition of managing difference and dissent in politics such that it can become a strength rather than source of discord. At the heart lies an informally institutionalized process of summitry and discussion in lieu of power politics. Escalation in Latin American terms means the convocation of presidential diplomacy to discuss the matter of dissent, not the deployment of military forces to border regions. More significantly, it is often not just the presidents of the directly effected countries that meet, but rather the region's leadership or a delegated sub-grouping of ministers or national presidents.

Although there are a series of semi-regular presidential summits through groupings such as Unasur, Mercosul, CELAC and so on, the concertacion process is not entrenched in a formalized framework, but rather exists as a convention embedded in the region's shared legalistic approach to international affairs. Chief amongst the legal norms driving concertación are the interlinked principles of sovereignty and non-aggression. Although precise interpretations are debated, there is cross-national agreement in Latin America that respect of international law is essential for mutual security and that great emphasis should be placed upon setting and observing the rules. Two interrelated factors play a role in this preference for talking through conflict rather than fighting it out. First is the comparative weakness of the armed forces throughout the region. Although individually capable, none of the region's armed forces have received the sort of investment necessary to make them a viable expeditionary force, a factor reflected in global military power rankings. Moreover, there is no popular or political desire to engage in this kind of expenditure, particularly in the face of the still considerable poverty challenges found in each regional country. Layered on top of this is a more cultural factor that points towards a general desire to find an amicable solution to disagreements. 
The depth of concertación strategies of avoiding military conflict have been highlighted over the last fifteen years as substantial increases in military expenditure by many regional countries have resulted in increases in mutual confidence, not a rise of distrust-fuelled arms races (Villa and Weiffen, 2014). According to the 2015 edition of the Stockholm International Peace Research Institute's (SIPRI) Military Expenditure Database, Latin American countries collectively spent USD 694 billion from 2005 to 2014, led by Brazil at USD 337 billion, Colombia at USD 105 billion, and Mexico at USD 59 billion. Significantly, this expenditure has not been driven by the rise of pressing external threats, but instead by a set of complex internal conflict-related and non-conflict-related motives connected to the new security challenges side-lined by US policy makers as well as national development concerns. For example, replacing and upgrading old weaponry is explicitly framed by countries such as Brazil as an avenue for building the national industrial base and accelerating domestic technological mastery in key fields such as engineering and information technology (Ministério da Defesa, 2012).

A central example of how the concertación mechanism works to defuse disagreements and prevent escalation to serious conflict came in July 2010 when the Colombia armed forces, acting on intelligence from the US, crossed over the border with Ecuador to bomb a base set up by the Colombian FARC insurgent movement. Ecuador was understandably incensed with the violation of its sovereignty and president Rafael Correa made his feelings clear to his Colombian counterpart Alvaro Uribe. Bolivian president Evo Morales voiced his disapproval and expressed strong support for Ecuador. Venezuelan president Hugo Chávez, who was never on a particularly friendly basis with Uribe, fulminated and went so far as to order his military to the border.

At this point the concertación institution was activated through a meeting of Unasur foreign ministers in Quito. Pressure to avoid a war no one in the region wanted came swiftly from countries as ideologically varied as Brazil, Chile and Peru, and extensive dialogue was initiated. The result was a rapid reduction in tensions and the path towards a South American presidential summit where Ecuador and Colombia agreed on a way forward for dealing with the FARC and the most vocal protagonists in the dispute - Uribe and Chávez - duly, if reluctantly gave each other a grande abrazo to officially set the unfortunate event in the past.

The concertación mechanism functions effectively in part because it is undergirded by a busy agenda of presidential and ministerial meetings every year, including those for well-known regional groupings like Mercosur, Unasur, CELAC and the OAS in addition to whatever bilateral visits and consultations may be scheduled. While these frequent meetings do not always result in shared positions or consensus on what the region should do, it does mean the different countries in the region are aware of each other's respective positions. Moreover, when a decision is made to take a collective position forward it often caries extra weight in global forums because it is grounded in a regional reconciliation of the same sorts of competing interests found at the international level. This was precisely the process that caused Zoellick so much angst in Cancun. The G20 position was not reached in an ad hoc manner at Cancun, but instead stemmed from extended discussions over the six months prior to the Ministerial meeting with India and Brazil organizing the member countries around the discussion of alternate positions. Similar approaches were seen in the Free Trade Area of the Americas talks when the Mercosur countries and increasingly the rest of South America worked to coordinate positions before heading to negotiating sessions with the US and Canada. Since the mid-2000s there has been a rise in intra-South American security coordination through the South American Defence Council. While not extending to become a 
classical security community - arguably something not necessary in South America - or a NATO-like entity, regular meetings, consultations, and joint exercises and training by the region's armed forces are further building mutual confidence in an area which is seeing significant increases in defence spending by a number of countries.

Another important trait of Latin American diplomatic culture underpinning the concertación process is what Brazilians call cordialidade. Presented by Brazilian historian Sergio Buarque de Holanda (2012), the concept is explained as being something of an opposition to AngloSaxon rational culture, suggesting instead that Brazilians "think with the heart" resulting in marked preference to avoid conflict and instead find a mutually amicable solution to pesky problems (Cervo, 2008; Kern, 2013). Advancement of personal and national interests is by no means discarded. Instead, greater effort is devoted to searching out space where contending desires can be aligned, not cast in opposition.

Extending the idea of cordialidade to Latin American international relations, the concept provides an emotionally grounded explanation for the solidity of Merke's concertación process of diplomatic management. In practical terms it can quite literally result in regional presidents being encouraged by their peers to step back from the brink to 'hug it out'. Thus, cordialidade as an attribute of presidential leadership is not a mere gesture of politeness, but a political tool to mediate and approximate distant or extreme behaviours with a "familial" mediation quietly conducted behind closed doors, not aired in public. As former Brazilian president Fernando Henrique Cardoso recounts in his memoires, the 1999 Ibero-American Summit in Havana saw this process in action when successive Latin American leaders bluntly warned Castro he needed to liberalize political and economic life on the island or risk losing all his regime had accomplished. Tellingly, these warnings were delivered at the closed doors dinner amongst the leaders and not repeated in any of the public events related to the Summit (Cardoso, 2006: 640-643).

- An informally institutionalized habit of frequent presidential summits facilitates the concertación process, which allows the resolution of disagreements before they become serious conflicts.

- The international legal principles of sovereignty and non-aggression are the cornerstone of the common normative framework underpinning Latin American diplomatic practice

- Parallel legal and cultural histories contribute to a foreign policy habit of talking until consensus is reached rather than engaging in unnecessary high stakes brinkmanship.

\section{Autonomist collectivization}

There is certainly space for forgiving casual observers of Latin American foreign policy who insist on seeing the region as a single entity despite its heterogeneity. Although it is very difficult to successfully argue there is a common approach to foreign policy throughout the Americas (Hey, 1997; Hey, 1998; Mora and Hey, 2003; Gardini and Lambert, 2011), we can usefully talk about one large shared concern. Irrespective of how a specific country in Latin America goes about framing its foreign policy strategies, an underlying concern is with the preservation of autonomy. The pattern of US foreign policy towards Latin America briefly outlined above carries with it a long tradition of either directly intervening in the region or bringing enormous pressure to bear on regional countries, which in turn provides some of the rationale underpinning the turn to a habit of concertación in the region. 
The repeated response from Latin American countries to these pressures has been to collectivize positions through ad hoc groupings. Whether in trade talks such as the WTO and FTAA, inter-American political forum such as the OAS, or international organizations such as the UN, it is not unusual to see groups of like-minded Latin American countries picking from the panoply of regional groupings to not only add density to their position, but also gain political shelter through collectivization. An insightful case in point was the 2005 Organization of American States General Assembly where the almost forgotten ALADI trade grouping was revived to kill the host US's proposal to turn the OAS into a type of hemispheric democratic policeman.

Joint action is also seen on a more localized level. In Canberra the Latin American diplomatic community has informally become know as the 'wolf pack' because of its willingness to join forces in search of access to the Australian Government that might otherwise be impossible. For example, where the Australian foreign minister might be reluctant to meet individually with the ambassador from El Salvador, Colombia or even Brazil, the prospect of covering an entire region with a single meeting combining the Latin American diplomatic corps has proven an attractive engagement option with ministers from all sides of the political spectrum.

Both the concern with protecting national autonomy and collectively acting on an ad hoc basis to secure it have very strong intellectual roots in the region, particularly in the dependency analyses stemming from the hard empirical research conducted by the United Nations Economic Commission for Latin America and the Caribbean (ECLAC) in the 1950s and 1960s. The path-breaking research by Raúl Prebish (1951) published in the first ECLAC economic survey of the region set out the problem of declining terms of trade, which meant the region's natural resource exporting countries would constantly have to sell increasing volumes of product to maintain the same income. Compounding the challenge of constantly declining values of national exports was the need to rely on areas like the US and Europe not only for the capital needed to develop, but also for the technology to keep pace economically. Pushing the analysis further, the more critical elements of the dependency school put forward arguments that the Northern core countries were engaged in an almost calculated set of policies to ensure Latin American countries would remain dependent and underdeveloped.

Arlene Tickner (2014) has translated the essence of Prebisch's declining terms of trade argument into foreign policy practice, arguing that an 'autonomist' strategy permeates the region. The central challenge she highlights for regional foreign policy planners is one of maintaining a degree of national policy autonomy to purse the domestic and international goals of the country in question. Three factors are central to the common problématique faced by most Latin American diplomats. The first relates to economic power and the challenges countries in the region have historically faced with growing the economy while managing precarious debt levels and unstable financial systems. This automatically restricts the room for manoeuvre and effectively limits the range of open foreign policy options.

Second is a straightforward question of policy independence. Autonomy as conceived by Max Weber (1978) assumes that there is a difference between "a mere freedom of contract" and the privilege of "regulating his relations with others by his own transactions". This differentiation is central to understand Tickner's characterization of a Latin American view of the world, what she calls Latin America hybrid approach drawing on elements of dependency theory, classical realism and complex interdependence. Under the Latin American hybrid approach hierarchical relations of domination and interdependence characterize the international system. The state, viewed in relatively non-problematic terms, becomes the 
principal actor in the international sphere, followed by other types of economic actors such as multinational corporations.

The Twentieth Century contains many examples of the US exerting enormous political pressure on countries in the region to follow specific domestic and international policy tracks. While the directness of this pressure has certainly varied from de facto invasion in parts of Central America to supportive backroom whisperings to the generals of 1960s Brazil, what remains common is the existence of a persistent external lobby on national governments. Much of the anti-American bluster of 2000s foreign policy discourse in countries as varied as Venezuela, Argentina, Ecuador and Brazil has been a direct response to the history of direct and indirect US infringement of national autonomy in the region. Significantly, the heated rhetoric has frequently proven to be little more than a smokescreen for public consumption while bilateral cooperation continues to grow quietly in the background.

Both of these first two elements are reflected in the third factor, which is a general political, economic and military weakness on the global stage, which creates serious challenges for many regional countries seeking to advance and protect their national interests. The danger here is that agreements framed and rules written in international institutions will place unwanted restrictions on the national autonomy of regional countries and further marginalize their position at global decision-making tables. Here the habit of concertación has proven particularly useful for working not only collectively to protect the autonomy of Latin American governments, but also for collaborating with governments from other regions to advance shared concerns. Married to this has been an attitudinal shift throughout the Americas in the 2000s that has seen a dramatic rise in the self-confidence of various regional countries to pursue independent foreign policies (Burges, 2005). Examples include Venezuela's hard turn to the left with its Bolivarian initiatives, Brazil's push to expand SouthSouth linkages with a major emphasis on Africa, and the formation of the Westward-oriented Pacific Alliance by Chile, Colombia, Mexico and Peru. In each of these examples the new direction has been followed without any apparent need for US approval, be it passive or active.

The rising sense of self-confidence and willingness to proactively advance national foreign policy priorities is also found amongst the traditionally minor international players in the region. A case in point is Paraguay's active involvement within the WTO as a vocal protagonist in the small land-locked states movement during the 2000s. In addition to consistently raising the challenges faced by land-locked countries within the WTO's global trading regime, the otherwise diplomatically near-silent Paraguay went so far as to convene a meeting of thirty-one land-locked countries in Asunción in 2005 to articulate a series of shared concerns and search for common approaches to shared Doha round concerns (Oxford Analtyica 2005).

- Repeated pressures from the US have created a habit in Latin America of looking for collective solutions and seeking strength in numbers behind common positions.

- Collective Latin American positions in international forum gain traction because they reflect an intra-regional reconciliation competing interests similar to those at the global level.

- A central, unifying goal of Latin American foreign policy is maintenance of domestic policy autonomy.

- Regional countries happily collaborate when necessary, but are equally content to independently pursue their core diplomatic agenda. 


\section{Structural, not relative power games}

Paraguay's attempts to coordinate an issue-specific negotiating coalition within the WTO share a significant conceptual similarity with the Cancun ministerial meeting story at the start of this chapter. Much of mainstream North American international relations theory is focused on questions of relative power and capability. Indeed, foreign policy analyses and the investigation of diplomatic strategies are focused on motivations crossed with capacities to pursue specific goals. The focus consequently becomes one of having enough power to compel the action of another actor to proceed in manner it might not otherwise choose. While questions of relative power are not absent from Latin American diplomatic practice, the underlying autonomist imperative and the practice of concertación have shifted practical focus from questions of relative power to those of structural power.

One of the common foundational challenges Latin American diplomats have historically had to address when seeking to engage a new issue on the global stage is how they would obtain not just access to the discussion process, but also a voice at the table bringing some impact on the end result. Drawing on the autonomist principles outlined by Tickner, the recurring problem diplomats from nearly all regional countries lament is the extent to which the nature of the international system - the structures of global governance - actively marginalize all but a handful of core countries. Magnifying this challenge is a predominantly North Atlanticdriven focus that side lines the serious questions of socio-economic development that are the main public policy concern in Latin America, but an esoteric philanthropic foreign aid endeavour for Northern governments.

Latin American diplomacy is consequently focused tightly on what Susan Strange (1994) would have called questions of structural power, aiming to redirect not just the terms of debate in the international system, but also how international institutions operate. The result is an apparent focus on multilateralism and the development and activation of international regimes and organizations. In part this is necessary because even if the largest regional countries like Brazil and Mexico had the inclination, they lack the material and political resources needed to advance their agenda by wielding relative power differences to impose their will. Attention is consequently turned to contesting and reinterpreting international norms and the institutions enforcing and supporting them. While this can create an impression that various Latin American countries are at times being obstructionist or wantonly destructive, reality is somewhat more complicated. Engagement with global governance structures is underpinned by an abiding desire to maintain the current international system, but in a form that is more 'inclusive' and 'democratic'. After all, the existing normative and institutional framework provides an effective security blanket and clear set of rules within which to pursue national development goals.

What is contested is the 'undemocratic' nature of some of the global governance frameworks, which are seen to be excessively captured by Northern interests. One of the recurrent examples highlighted by Latin American countries are the Bretton Woods Institutions, which have an entrenched voting pattern that ensures US and European economic interests will continue to prevail irrespective of shifts in global economic power. The response from the region is not disengagement with these institutions, but rather the erection of parallel systems that offer alternatives. In this context most analysts would immediately point to the rise of the BRICS Bank and its enthusiastic embrace by many Latin American countries. More telling are small institutions, such as the Banco del Sur, which is a sort of mini Inter-American Development Bank intended to advance regional infrastructure investment. On a technocratic 
level the ALADI Reciprocal Credit Convention offers an avenue for bypassing Northern financial intermediation by facilitating direct currency transfers between member countries via Central Bank swaps that avoid the need to translate transactions into US dollars. The point to these examples is not that they seek to challenge or overturn the existing global economic governance system, but rather that they look to broaden it and thus improve the structural insertion of regional countries, which in turn works to vouchsafe a bit more autonomy and independence.

- Latin American diplomacy is predominantly concerned with questions of structural power relating to the rules and norms of the international system, not relative power concerns about forcing action by other countries.

- A shared perception in the region is that Latin American interests are structurally excluded from global governance regimes reflecting North Atlantic priorities.

- Many global governance institutions such as the World Bank are perceived throughout Latin America as being fundamentally undemocratic in nature and operation.

\section{Development as priority}

For over a century Latin American foreign policy has focused on the 'dream of development,' seeking to modernize the region's predominantly rural, enclave economies and transform them into industrialized, high consumption societies. In diplomatic terms the problem facing Latin America has been structural in that the terms of reference for international debates and negotiations either do not include the region's legitimate developmental concerns or assumes they are historical curiosities of little concern to serious countries. The persistent challenge has thus been to get past a preconceived notion of Latin American countries as being financial basket cases or banana republics condemned to the role of commodity producer.

One of the strategies Latin American countries have pursued in an effort to accelerate domestic socio-economic development has been the formation of regional blocs. While this tradition extends back to the 1960s, it is only after the lost decade of the 1980s that region formation in Latin America appears to have taken effective form. Where previous attempts at economic regionalism were marked by high levels of protectionism and internal squabbles about the distribution of industrial production sites, the wave of blocs formed from the 1990s represent a different type of endeavour explicitly aiming to collectively achieve enhanced insertion in the post-Cold War globalized economy as a new route to national development. The turn to the 'new' regionalism in the 1990s also combined with the region's transition to democracy, interweaving processes of economic and political liberalization such that domestic reforms were buttressed by a regional environment not only conducive to change, but actively supportive of it.

In the first half of the 1990s, the Andean Pact (Bolivia, Peru, Ecuador, Colombia, Venezuela) intensified integration through an 'Open Skies' policy and established a free trade zone and a common external tariff. Similarly, negotiations extending back into the early 1980s led directly to 1990 talks to form a common market between Brazil and Argentina, which resulted in the 1991 Treaty of Asunción joining those two countries as well as Paraguay and Uruguay into the Common Market of the South, Mercosur. Both the Andean Pact and Mercosur followed a broadly neoliberal agenda focused on opening markets and 'behaving well', economic strategies used by diplomats to establish the region internationally as one of serious, politically and economically stable countries worthy of investment and inclusion in global governance councils. Perhaps the ultimate expression of this came with Mexico's formation 
of NAFTA with Canada and the USA in 1994. The combined effect of these different processes apparently had some serious impact on US attitudes towards the region, prompting the Clinton presidency to propose the formation of a Free Trade Area of the Americas at the 1994 Miami Summit of the Americas (Arashiro 2011).

A decade into the Twenty-First Century much of the economic steam appeared to have gone out of the regional projects launched in the 1990s. Squabbles over market access marred the most successful example, Mercosur. Notions of expanding the Southern Cone bloc into a wider Union of South American Nations, Unasur, appeared to lack the necessary economic fundament, particularly if a hard look was taken at intra-South American trade. Matters are further confused if attention is turned to the institutional frameworks for these regional projects. Mercosur has yet to make effective use of its internal dispute resolution system and the bloc's parliament remains something of a toothless kitten (Malamud and Dri 2013). On a continental level Unasur lacks any substantive decision making power and one of its most interesting ventures the South American Defence College has yet to begin actual pedagogical operations. Even the most expansive Latin American venture, the Community of Latin American and Caribbean Nations CELAC, has neither a permanent home, nor an institutionalized secretariat.

Despite the myriad challenges facing the various regional groupings throughout Latin America, the turn to regionalism persists. A significant factor contributing to the perseverance of the regionalist ethos in Latin America lies in the very developmental prerogatives central to this section of the chapter. Latin American countries have adopted integration processes as an expression of their need to grow, be recognised, and deal with their global governance demands. Although Unasur lacks economic substance, it has made great strides in health policy coordination (Riggirozzi 2014) and confidence building amongst the region's military forces. Mercosur's apparent unending economic tensions create serious challenges for the respective member-state presidents, but also compel frequent high level meetings to coordinate international negotiating positions as well as the sharing of expertise in more prosaic areas of public policy such as phytosanitary controls in the cattle industry or the cross border provision of health and education services in remote areas. On a scholarly level academics have begun referring to the persistence of regional cooperation in the Americas as the rise of 'post-hegemonic' regionalism, meaning inter-state cooperation and coordination driven by something other than neoliberal economic principles (Riggirozzi and Tussie 2012). While the aptness of this characterization is open to debate, the sense that regionalism is offering non-fungible development goods and that these are central foreign policy goals in Latin America is a consideration to keep in mind when treating with Latin American diplomatic agendas.

- National socio-economic development remains the overriding public policy priority throughout the region and has a major influence on diplomatic practice

- The formation of regional blocs has emerged as one strategy for attempting to accelerate national development and collectively enhance influence internationally.

- While regional integration may seem to be questionable as an economic success in the region, it has offered significant benefits in terms of capacity building and the sharing of best practices in social and development policy. 


\section{Conclusion}

As we have argued in this chapter, there is a mistaken tendency to view Latin America as near-homogeneous whole with shared foreign policy priorities. The confusion stems from a double movement in regional diplomacy that sees simultaneous coordination and fragmentation between Latin American states. A degree of unification amongst the region's countries stems from the need to manage relations with the US, which historically has often approached Latin America as a single entity that can be marginalized and manipulated to suit the political whims of Washington. Resisting this pressure and preserving space for autonomous policy making on a domestic and regional level has frequently driven Latin American countries to act in what seems like a bloc. But, as this chapter explains, viewing the region as a unity overstates the extent to which there is commonality of purpose and ambition. Rather than the language of alliance, we argue a better understanding can be found in the concepts of concertación and cordialidade.

The idea of concertación eliminates the false notion of regional unity and instead unpacks the ad hoc nature of intra-regional cooperation and the habits of, if not coordination, at least advance notification to neighbours of diplomatic positions on regional and international issues. If a coalition is useful, it is formed; if not, dissent and conflict is avoided through communication. This points to cordialidade, the second central element for understanding Latin American diplomacy. It is not so much that conflict must be avoided, but rather than efforts should be devoted to minimizing its deleterious impacts in order to keep disagreements at the level of friendly differences of opinion, not national security threatening clashes of will. Application of these two concepts is increasingly being fed by a growing sense of selfconfidence throughout the region as the legacy of the commodity boom, internally driven development and shifts in global power patterns increase the range of options that countries see open. The extent to which this will result in significant changes in the patterns of diplomatic behaviour mapped out in this chapter remains to be seen.

\section{References}

Arashiro, Zulieka (2011). Negotiating the Free Trade Area of the Americas. Basingstoke: Palgrave Macmillan.

Burges, Sean. Auto-Estima in Brazil: The Rhetorical Logic of Lula's South-South Foreign Policy. International Journal, v. 60, n. 03, p. 1133-1151, 2005.

Cable, Vincent (1969). The 'Football War' and the Central American Common. International Affairs, v. 45, n. 04, pp. 658-671.

Cardoso, Fernando H. and Faletto, Enzo (1979). Dependency and Development in Latin America. University of California Press.

Cardoso, Fernando Henrique (2006). A arte da politica: a história que vivi. Rio de Janeiro: Civilização Brasileira.

Cervo, Amado (2008). Inserção Internacional: formação dos conceitos brasileiros. São Paulo: Saraiva, 2008.

de Holanda, Sérgio Buarque (1995). Raízes do Brasil. 26.ed. São Paulo: Cia. das Letras. 
de Holanda, Sérgio Buarque (2012). O homem cordial. São Paulo: Cia. das Letras.

Farcau, Bruce W. (1996). The Chaco War: Bolivia and Paraguay, 1932-1935. USA:

Greenwood Publishing Group.

Flemes, Daniel and Leslie Wehner (2013). Reacciones estratégicas en Sudamérica ante el ascenso de Brasil. Foreign Affairs Latinoamérica 13(4): 107-114

Gardini, Gian Luca and Peter Lambert, eds. (2011) Latin American Foreign Policie: Between Ideology and Pragmatism (New York: Palgrave Macmillan).

Hakim, Peter (2006) “Is Washington Losing Latin America?” Foreign Affairs 85 (1): 39.

Hey, Jeanne A. K. (1997) "There Building Blocks of a Theory of Latin American Foreign Policy," Third World Quarterly 18 (4): 631-658.

Hey, Jeanne A. K.(1998) “Is There a Latin American Foreign Policy?” Mershorn International Studies Review 42: 106-116.

Kenkel, Kai Michael, ed. (2013) South America and Peace Operations: Coming of Age (Abingdon: Routledge)

Kern, Felipe (2013). Seria a 'Cordialidade Oficial Brasileira', a Diplomacia Do 'Homem Cordial'?. Conjuntura Austral, v. 04, n. 18, pp. 27-40.

Lochery, Neill (2014) Brazil: The Fortunes of War (New York: Basic Books).

Malamud, Andrés and Clarissa Dri (2013) "Spillover Effects and Supranational Parliaments: The Case of Mercosur," Journal of Iberian and Latin American Research 19 (2): 224-238.

Merke, Federico (2015) "Neither balance nor bandwagon: South American international society meets Brazil's rising power," International Politics 52 (February): 178-192.

Ministério da Defesa (2012) Livro Branco de Defesa Nacional (Brasília: Ministério da Defesa).

Mora, Frank O. and Jeanne A . K. Hey, eds. (2003) Latin American and Caribbean Foreign Policy (Lanham, MD: Rowman and Littlefield).

Muñoz, Heraldo (2008). A Solitary War: A Diplomat's Chronicle of the Iraq War and Its Lessons. Golden, CO: Fulcrum Publishing.

Oppenheimer, Andrés (2007), Saving the Americas: The Dangerous Decline of Latin America and What the U.S. Must Do (Mexico: Random House Mondadori).

Oxford Analytica (2005) "Limited traction for landlocked group," Oxford Analytica Daily Brief(23 August).

Prebisch, Raúl (1951), "Growth, Balance and Disparities: Interpretations of the Economic Development Process," in CEPAL, Economic Survey of Latin America, 1949 (Santiago: United Nations). 
Riggirozzi, Pía (2014) "Regionalism through social policy: collective action and health diplomacy in South America," Economy and Society 43 (3): 432-454.

Riggirozzi, Pía and Diana Tussie, eds. (2012) The Rise of Post-Hegemonic Regionalism: The Case of Latin America (London: Springer).

Schenoni, Luis Leandro (2014) "Unveiling the South American Balance," Estudos Internacionais 2 (2) (jul-dez): 215-232.

Starbroek News (2007). "Venezuela replies to incursion note". Starbroek News [online]. 12 December 2007. Available in:

[http://www.stabroeknews.com/2007/archives/12/12/venezuela-replies-to-incursion-note/]. Accessed in: 20 September 2015.

Strange, Susan (1994) States and Markets, $2^{\text {nd }}$ ed. (London: Pinter Books).

Tickner, Arlene (2003). Hearing Latin American Voices in International Relations Studies. International Studies Perspectives, v. 04, n. 04, pp. 325-350.

Tickner, Arlene B (2014) “Autonomy and International Relations Thinking” in Jorge I. Domínguez and Ana Covarrubias (eds.) Routledge Handbook of Latin America in the World (New York, NY: Routledge): pp. 74-84.

Villa, Rafael A. Duarte, and Brigitte Weiffen (2014) "South American Re-armament: From Balancing to Symbolizing Power," Contemporary Security Policy 35 (1): 138-162.

Villa, Rafael; Ribeiro, Thiago; Chagas Bastos, Fabrício (2015). South America in the PostCold War Era: war on drugs and the reshaping of the US security agenda. Revista da Escola de Guerra Naval (forthcoming)

Villa, Rafael. O Paradoxo da Macrossecuritização: Quando a Guerra ao Terror não Securitiza Outras 'Guerras' na América do Sul. Contexto Internacional, v. 36, p. 349-383, 2014.

Weber, Max (1978). Economy and Society. v.02. University of California Press.

Zoellick, Robert (2003). Confrontations Doomed WTO Cancun Meeting. Financial Times 